\title{
Calendar Anomalies and Turkish Real Estate Investment Trusts (REITs)
}

\author{
Ali HEPŞEN \\ Department of Finance, Faculty of Business Administration, Istanbul University \\ Istanbul, 34000, Turkey \\ Tel: 90-212-473-7070 ext. $18321 \quad$ E-mail: alihepsen@yahoo.com
}

\author{
Received: November 29, 2011 \\ Accepted: January 17, $2012 \quad$ Published: March 1, 2012 \\ doi:10.5539/ijef.v4n3p230 \\ URL: http://dx.doi.org/10.5539/ijef.v4n3p230
}

\begin{abstract}
This study investigates the presence of calendar anomalies (January Effect; Day of the Week Effect; Turn of the Month Effect) on the daily returns at Istanbul Stock Exchange (ISE) real estate investment trusts (REIT) market. Although there have been numerous studies in the finance literature on the existence of calendar anomalies in common stocks but a few studies of anomalies in the markets for REITs. The research covers the period of January 4, 2000 to December 31,2010, and the empirical study applies the ordinary least squares (OLS) model with dummy variables to investigate the calendar effects. The results prove that the daily returns of ISE REIT Index in January shows a statistically significant difference from other months. For the day of the week anomalies, statistics indicate that ISE-REIT Index daily returns on Tuesdays, Wednesdays, Thursdays and Fridays are significantly higher than the returns on Monday. This provides evidence of a day of the week effect in the market. On the other hand, the average return in turn of the month trading days is significantly higher than the average return in non turn of the month trading days and that is the existence of the turn of the month effect. In addition, there is no any previous study analyzing the calendar anomalies in REIT market. At this point, this paper is the first academic study that investigates anomalous behavior in REIT returns in Turkey.
\end{abstract}

Keywords: Real Estate Investment Trusts (REITs), Calendar anomalies, January effect, Day of the week effect, Turn of the month effect

JEL Classification: G12; G23; G29

\section{Introduction}

Real estate investment trusts (REITs) are closed-end investment companies which are managing portfolios composed of real estates, real estate based projects and capital market instruments based on real estates. They serve as financial intermediaries to facilitate the flow of funds from investors to real estate sector of the economy (Corgel et.al, 1995). The firstly introduction of the REITs in Turkey in 1995 opened the door for making real estate investments more widely available to individual and institutional investors. The main goal of REITs in Turkey is to create a source of financing for the real estate sector, which has been experiencing problems in this area. In order to promote the formation and growth of the industry, authorities have provided REITs with some important tax incentives as well as flexibility in managing their portfolios. On the other hand, Turkish REITs are not required to pay out dividends on an annual basis that is they have freedom to choose their dividend policy (Erol and Tirtiroglu, 2011). As of June, 2011, there are 23 REITs registered with the Capital Markets Board of Turkey and listed on the Istanbul Stock Exchange (ISE) with a total portfolio of US\$11,808 billion. However, apart from the ones already on the ISE, this number is expected to rise and the total portfolio to grow with new public offerings in the years ahead. Table 1 presents the historical consolidated portfolio structure of REITs in Turkey.

The main purpose of this paper is to provide an examination of three calendar anomalies (the January effect, the day of the week effect, and the turn of the month effect) in ISE REIT market. The results of this study would help individual and institutional investors for creating more effective investment strategies. If such calendar anomalies exist, opportunities may arise for earning abnormal returns on REIT stocks. The layout of the remainder of this paper is organized as follows. The literature review discusses the related literature on the calendar anomalies for REITs. The data section describes the sample. The methodology and the empirical results section provide an overview of the methodologies and present the results of the empirical tests. The final section provides some concluding remarks. In addition, there is no any previous study analyzing the calendar anomalies in REIT market. At this point, this paper is the first academic study that investigates anomalous behavior in REIT returns in Turkey. 


\section{Literature Review}

In finance, an efficient capital market suggests that security prices adjust rapidly and accurately to new information and always "fully reflect" all available information (Fama, 1965). The issue of efficiency in the financial markets has been widely investigated by determining the behavioral characteristics of the prices of securities. The unusual behaviors of the prices, anomalies, are divided into subgroups, and one of the subgroups is called calendar anomaly. The literature on calendar anomalies is vast and dates back many decades. Most of the research on anomalies in stock markets has concentrated on the day of the week effect, the turn of the month effect, and the January effect. French (1980), Ariel (1987), and Rozeff and Kinney (1976) were the first researchers who exhaustively investigated these three price irregularities, which contradict the efficient market hypothesis. There have been numerous studies in the finance literature on the existence of calendar anomalies in common stocks but a few studies of anomalies in the markets for real estate investment trusts.

A major finding in most of the existing studies on monthly seasonality in stock markets is the January effect. That is abnormally high stock returns generated in January compared to the rest of the year. The first study on the existence of the January effect in the returns of real estate related stocks was by Colwell and Park (1990), who constructed an equally weighted return index based on monthly Center for Research in Security Prices (CRSP) data for the period from 1964 through 1986 to examine whether the January effect was also present in the REIT market. The main conclusion of their research is that the average rate of return on REITs is highest in January, but this is more apparent among small REITs. Similar research with comparable results was performed by Friday and Peterson (1997) for US REITs over the period 1974 to 1993. In this research, the authors find evidence, which indicates that the January effect is caused by tax-loss selling. Redman et al. (1997) examined the January effect in addition to three calendar anomalies for the period 1986 through 1993. They indicated that trading in January provided greater returns for REITs. More recently, Connors et al. (2002) re-examined the January effect in US REIT market over a period of 6 years, from 1994 through 1999. Contrary to other published researches, they found little or no evidence for the existence of the January effect in REITs. Instead, their results indicated that a December effect with returns significantly higher in Office/ Industrial, Retail and Multifamily Housing sectors. Hardin et al. (2005) re-examined the January effect over the period January 1994 to December 2002 in US REIT equally and value weighted indices. REITs did not evidence a January effect as measured by the REIT value-weighted index. By contrast, the REIT equal-weighted index supported a January effect anomaly.

As mentioned, the market efficiency hypothesis suggests that security prices adjust rapidly and accurately to new information. One of the most important issues is the day of the week anomaly in the market efficiency hypothesis. That is defined as a pattern of relatively low returns for some days of the week (i.e. Mondays) and relatively high returns for some other days of the week (i.e. Fridays). With regard to the literature on the day-of-the-week effect, the returns of REITs were first examined by Redman et al. (1997). For the period 1986 to 1993 they documented both significant negative returns on Mondays and a gradual increase in the returns as the week progresses, with the highest returns occurring on Friday. Although the returns on Mondays for the common stock portfolios are the lowest of the week too, the patterns are different from the REIT returns. Given the similarities between the equally weighted portfolio and the REIT index they conclude that the day of the week effect seems to be most prominent among small firms. Friday and Higgins (2000) examined the behavior of REIT returns around the weekend from 1972 to 1995 . They reported that the average returns on Mondays to be positive when returns on Friday were positive and returns on Monday were negative when returns on Friday were negative. The relation between Monday returns of REITs and the changes in REIT structures in the late 1980s is investigated by Chan et al. (2005). They found that the disappearance of the lower and negative returns on Mondays coincided with an increase in the number of institutional investors in the REIT market, that is, no Monday anomaly was found in the case of US REITs. Brounen, and Yair (2009) examined the pattern of REIT returns around the weekend from 1987 to 2007 and found that returns on Thursday and Friday were significantly positive, but that returns on Monday were insignificantly positive in the US REIT market during the period from 1997 to 2007. Finally, in a recent study by Lee and $\mathrm{Ou}(2010)$ the day of the week effect is examined by using Value at Risk (VaR). Researchers found that there were positive returns on Tuesday and Friday, and negative returns on Wednesday.

The turn of the month is a market anomaly where stocks appear to earn abnormal returns during the last few days of one month through the first few days of the next. Redman et al. (1997) are the first to document a turn of the month in REIT stocks. In their research the dummy variable, for the turn of the month effect, be covering the last and the first three trading days of the month. They found evidence of a turn of the month effect and investors could earn higher returns by trading at the turn of the month in REIT shares. Connors et al. (2002) verified the continued pattern for REITs to experience positive returns around the turn-of-the-month, and noted that the returns during the rest of the month are insignificantly different from zero. Compton et al. (2006) examined the market returns of five 
REIT indices (real estate 50 REIT, all-REIT, equity REIT, hybrid REIT, and mortgage REIT) to determine whether they exhibited a turn of the month (TOM) effect. They found that the six-day TOM period, on average, accounted for over 100 per cent of the monthly return for the three non-mortgage REITs, while the rest of the month (ROM) period generated a negative return. Additionally, the TOM returns were greater than the ROM returns in 75 per cent of the months. The other recent study by Wiley and Zumpano (2009) measured the impact of the level of institutional investment on the turn-of-the-month effect using a sample of 238 REITs over the period 1980 to 2004.

\section{Overview of Data}

The objective of this study is to provide an examination of the January effect, the day of the week effect, and the turn of the month effect anomalies in ISE-REIT market (Note 1). To achieve this objective, a total of 2,730 daily observations for the whole operation period of ISE-REIT Index (from January 4, 2000 to December 31, 2010) are employed. REIT daily percentage returns in each month are calculated as follows:

$$
\mathrm{R}_{\mathrm{j}, \mathrm{t}}=\left[\left(\mathrm{l}_{\mathrm{j}, \mathrm{t}}-\mathrm{l}_{\mathrm{j}, \mathrm{t}-1}\right) / \mathrm{l}_{\mathrm{j}, \mathrm{t}-\mathrm{1}}\right]^{*} 100
$$

where $\mathrm{l}_{\mathrm{j}, \mathrm{t}}$ and $\mathrm{R}_{\mathrm{j}, \mathrm{t}}$ denote index number and return on day $t$ in month $\mathrm{j}$, respectively. Table 2 shows the descriptive statistics for REIT Index.

\section{Methodology and the Empirical Results}

This study uses the ordinary least squares (OLS) model with standard errors computed using the Newey-West (1987) autocorrelation and heteroscedasticity to investigate the calendar effects. Following Redman et al. (1997), the OLS model with the January effect is as follows:

$$
R_{t}=a_{1}+a_{2} D_{2 t}+a_{3} D_{3 t}+\ldots \ldots \ldots .+a_{12} D_{12 t}+e_{t}
$$

where, $R_{t}$ is the return on day $t ; D_{2 t} \ldots D_{12}$ are the dummy variables for the months, 1 if the trading day $t$ falls in the months of February through December, and 0 otherwise; $e_{t}$ is the random error term. In equation (2), the intercept $a_{1}$ is the average return in January. If the intercept is positive and significant, this indicates that the average return in January is significantly greater than zero. The coefficients $a_{2}$ to $a_{12}$ compare the average return in January with the average return in February through December. A positive and significant $a_{2}$ indicates that the returns in February are significantly higher than the returns in January. The coefficients for the remaining dummy variables, from $\mathrm{a}_{3}$ to $\mathrm{a}_{12}$, are also interpreted similarly. The $F$-value measures the joint significance of the coefficients. In addition to the parametric test, a nonparametric Kruskal-Wallis (KW) test is conducted to test the equality of returns. A significant $F$-value and $\mathrm{KW}$ test also supports the presence of a January effect. In addition, the $t$-statistics in $\mathrm{a}_{1}$ to $\mathrm{a}_{12}$ are adjusted for autocorrelation and heteroscedasticity up to 8 lags by using the Newey-West (1987) approach. The January effect results are shown in Table 3. Using the REIT index, the average daily return in January, measured by the constant, is positive and statistically significant at the $1 \%$ level. That is January behaves differently from the other months of the year, and for individual and institutional investors this generates a premium over the other months.

To analyze the day of the week effect in REIT index returns, equation 3 is utilized:

$$
R_{t}=a_{1}+a_{2} D_{2 t}+a_{3} D_{3 t}+a_{3} D_{3 t}+a_{4} D_{4 t}+a_{5} D_{5 t}+e_{t}
$$

where, $R_{t}$ is the return on day $t ; D_{2 t} \ldots D_{5 t}$ are the day of the week dummies; 1 if the trading day $t$ falls on Tuesday through Friday, and 0 otherwise; $e_{t}$ is the error term expected to follow regular normal regression assumptions. The intercept, $a_{1}$, measures the average daily rate of return on Monday. A positive and significant intercept implies that the average return on Monday is significantly greater than zero. The coefficients $a_{2}$ through $a_{5}$ are the pair wise comparison between the average return on Monday and the average return on Tuesday through Friday. A positive and significant $\mathrm{a}_{2}$ indicates that the returns on Tuesday are significantly higher than the returns on Monday. Similar interpretation is also applied to the remaining three dummy variables. A significant $F$-value and $\mathrm{KW}$ test also supports the presence of a day of the week effect. In addition, the $t$-statistics in $a_{1}$ to $a_{5}$ are the Newey-West (1987) $t$-statistics adjusted for autocorrelation and heteroscedasticity up to 8 lags. Table 4 contains the regression results for the day of the week effect. The constant term shows the average daily return that was earned on Mondays. On the other hand, the variables Tuesday, Wednesday, Thursday, and Friday are the dummy variables for the day of the week anomaly. As seen from the table, the coefficients for dummies are all positive and significant at the $1 \%$ level. These positive and significant coefficients imply that these returns are significantly higher than the returns on Monday. This provides evidence of a day of the week effect in REIT market.

To compare turn of the month and non turn of the month returns, the following regression with dummy variables representing the turn of the month trading days (explained in Ogden (1990) as "the final trading day of the previous month and the first three trading days of the current month") is employed in equation 4 :

$$
R_{t}=a_{1}+a_{2} D_{2 t}+e_{t}
$$


where, $R_{t}$ is the return on day $t ; D_{2}$ is the dummy variable for turn of the month trading day; 1 if the trading day $t$ is at the turn of the month, and 0 otherwise; $e_{t}$ is the random error term. The intercept, $a_{1}$, is the average return in non turn of the month trading days. If the intercept is positive and significant, this indicates that the average return in non turn of the month trading days is significantly greater than zero. The coefficients $\mathrm{a}_{2}$ compare the average return in non turn of the month trading days with the average return in turn of the month trading days. If $\mathrm{a}_{2}$ is positive and significant, this suggests that the average return in on turn of the month trading days is significantly higher than the average return in non turn of the month trading days and that is the presence of the turn of the month effect. A significant F-value and KW test supports the presence of a turn of the month effect. The $t$-statistics in $\mathrm{a}_{1}$ and $\mathrm{a}_{2}$ are also adjusted for autocorrelation and heteroscedasticity up to 8 lags by using the Newey-West (1987) approach. The parametric OLS regression model used to identify a turn of the month effect and the empirical test results are all exhibited in Table 5. The dummy variable for the turn of the month covers the last and the first three trading days of the month. The constant represents the average return in non turn of the month trading days. As seen from the table, the positive and the significant $\mathrm{a}_{2}$ suggests that the average return in turn of the month trading days is significantly higher than the average return in non turn of the month trading days and that is the existence of the turn of the month effect during the period from January 4, 2000 to December 31, 2010.

\section{Conclusion}

Real estate investment trusts are closed-end investment companies which are managing portfolios composed of real estates, real estate based projects and capital market instruments based on real estates. They serve as financial intermediaries to facilitate the flow of funds from investors to real estate sector of the economy. The firstly introduction of the REITs in Turkey in 1995 opened the door for making real estate investments more widely available to individual and institutional investors. There are now 23 REITs registered with the Capital Markets Board of Turkey and listed on the ISE REIT index. This study examines the behavior of ISE REIT market around the three calendar effects (the January effect, the day of the week effect, and the turn of the month effect) from 2000 to 2010. Although there have been numerous studies in the finance literature on the existence of calendar anomalies in common stocks but a few studies of anomalies in the markets for REITs. The empirical results of the OLS model reveal that January behaves differently from the other months of the year, and for individual and institutional investors this generates a premium over the other months. For the day of the week anomalies, statistics indicate that ISE-REIT Index daily returns on Tuesdays, Wednesdays, Thursdays and Fridays are significantly higher than the returns on Monday. This also provides evidence of a day of the week effect in the REIT market. In addition, the parametric OLS regression model finds a turn of the month effect during the period from January 4, 2000 to December 31, 2010. That is, the average return in turn of the month trading days is significantly higher than the average return in non turn of the month trading days.

Investigating these three price irregularities contradicted the efficient market hypothesis in ISE REIT market. The results of this study are also important to individual and portfolio managers for creating more effective investment strategies. That is opportunities may arise for earning abnormal returns on REIT stocks if investors trade in January, trade from Tuesday through Friday, and trade at the final trading day of the previous month and the first three trading days of the current month. On the other hand, for researchers the January effect, the day of the week effect, and the turn of the month effect have implications for asset pricing and performance evaluation.

\section{References}

Ariel, R.A. (1987). A Monthly Effect in Stock Returns. Journal of Financial Economics, 18 (1), 161-174. http://dx.doi.org/10.1016/0304-405X(87)90066-3

Brounen, D., \& Yair, B.H. (2009). Calendar Anomalies: The Case of International Property Shares. The Journal of Real Estate Finance and Economics, 38 (2), 115-136. http://dx.doi.org/10.1007/s11146-007-9088-9

Capital Markets Board of Turkey, Historical Consolidated Portfolio Structure Data, [Online] Available from: http://www.cmb.gov.tr (October 5, 2011).

Chan, S., et al. (2005). Changes in REIT Structure and Stock Performance: Evidence from the Monday Stock Anomaly. Real Estate Economics, 33 (1), 89-120. http://dx.doi.org/10.1111/j.1080-8620.2005.00113.x

Colwell, P.F., \& Park, H.Y. (1990). Seasonality and Size Effects: The Case of Real Estate Investment Trusts. The Journal of Real Estate Finance and Economics,3 (3), 251-260. http://dx.doi.org/10.1007/BF00216189

Compton, W.S. et al. (2006). The Turn of the Month Effect in Real Estate Investment Trusts (REITs). Managerial Finance, 32 (12), 969-980. http://dx.doi.org/10.1108/03074350610710463

Connors, D.N. et al. (2002). Calendar Anomalies in the Stock Returns of Real Estate Investment Trusts. Briefings in Real Estate Finance, 2 (1), 61-71. http://dx.doi.org/10.1002/bref.53 
Corgel, J.B., Mcintosh, W., \& Ott, S.H. (1995). Real Estate Investment Trusts: A Review of the Financial Economics Literature. Journal of Real Estate Literature, 3 (1), 13-43. [Online] Available from: http://ares.metapress.com/content/78343853v478h725/ (October 5, 2011).

Erol, I., \& Tirtiroglu, D. (2011). Concentrated Ownership, No Dividend Payout Requirement and Capital Structure of REITs: Evidence from Turkey. Journal of Real Estate Finance and Economics, 43 (1-2), 174-204. http://dx.doi.org/10.1007/s11146-010-9242-7

Fama, E.F. (1965). The Behavior of Stock Market Prices. The Journal of Business, 38 (1), 34-105. http://dx.doi.org/10.1086/294743

French, K.R. (1980). Stock Returns and the Weekend Effect. The Journal of Financial Economics. 8 (1), 55-69. http://dx.doi.org/10.1016/0304-405X(80)90021-5

Friday, H.S., \& Higgins, E.J. (2000). The Day of the Week Effect in Real Estate Investment Trusts. Journal of Real Estate Portfolio Management. 6 (3), 273-282. [Online] Available from: http://ares.metapress.com/content/ $\mathrm{k} 604 \mathrm{j} 476 \mathrm{v} 3 \mathrm{r} 4 \mathrm{w} 20 \mathrm{w} /$ ? $\mathrm{p}=\mathrm{c} 743 \mathrm{fe} 2 \mathrm{~d} 1$ ef548dbbeef2f83c7486402\&pi $=5$ (October 2, 2011).

Friday, H.S., \& Peterson, D.R. (1997). January Return Seasonality in Real Estate Investment Trust: Information vs. Tax-Loss Selling Effects. Journal of Financial Research, 20 (1), 33-51. [Online] Available from: http://econpapers.repec.org/article/blajfnres/default20.htm (October 1, 2011).

Hardin. W.G., et al. (2005). Real Estate Investment Trusts and Calendar Anomalies: Revisited. International Real Estate Review, 8 (1), 83-94. [Online] Available from: http://www.umac.mo/fba/irer/papers/past/vol8/v8n 1a04.htm (October 5, 2011).

Istanbul Stock Exchange. (2011). ISE REIT Index Data, [Online] Available from: http://www.ise.org/ Data/StocksData.aspx?sfopl=true (September 12, 2011).

Lee, Y.H., \& Ou, H.L. (2010). The Day of the Week Effect and Value at Risk in Real Estate Investment Trusts. Journal of Real Estate Portfolio Management, 16 (1), 21-28. [Online] Available from: http://ares.metapress.com/ content/7224w6727k671033/?p=14ab0420288b40c09b24f003efa8d431\&pi=3 (October 3, 2011).

Newey, W.K., \& Kenneth D.W. (1987). A Simple, Positive Semi-Definite, Heteroskedasticity and Autocorrelation Consistent Covariance Matrix. Econometrica, 55 (3), 703-708. http://dx.doi.org/10.2307/1913610

Ogden, J.P. (1990). Turn of the Month Evaluation of Liquid Profits and Stock Returns: A Common Explanation of the Monthly and January Effects. Journal of Finance, 45 (4), 1259-1272. http://dx.doi.org/10.2307/2328723

Rozeff. M.S., \& Kinney Jr, W.R. (1976). Capital Market Seasonality: The Case of Stock Returns. Journal of Financial Economics, 3 (4), 379-402. http://dx.doi.org/10.1016/0304-405X(76)90028-3

Redman, A.L. et al. (1997). Real Estate Investment Trusts and Calendar Anomalies. Journal of Real Estate Research, 14 (1), 19-28. [Online] Available from: http://ares.metapress.com/content/734445r75u1n0860/ (October 1, 2011).

Wiley, J.A., \& Zumpano, L.V. (2009). Institutional Investment and the Turn of the Month Effect: Evidence from REITs. The Journal of Real Estate Finance and Economics, 39 (2), 180-201. http://dx.doi.org/10.1007/s11146-008-9106-6

\section{Notes}

Note 1. Istanbul Stock Exchange (ISE) designs different types of indices so as to enable investors to track the ISE markets. Respectively, 46 and 18 indices are computed for the stock market and the bonds and bills market. Stock market indices calculated include both the price and return indices. While price indices reflect only the change in prices, dividend payments are also taken into account in return indices. The REIT index consists of stocks of real estate investment trusts traded on the ISE market. REIT index series are also set at 21,180.77 at the last trading day of 1999 . 
Table 1. Historical Consolidated Portfolio Structure of REITs in Turkey

\begin{tabular}{|l|c|c|c|c|c|c|c|c|}
\hline \multicolumn{7}{|c|}{ All Real Estate Investment Trusts } \\
\hline Year & $\begin{array}{c}\text { Number of } \\
\text { REITs }\end{array}$ & $\begin{array}{c}\text { Portfolio Value } \\
\text { Million USD\$ }\end{array}$ & $\begin{array}{c}\text { R } \\
(\%)\end{array}$ & $\begin{array}{c}\text { RP } \\
(\%)\end{array}$ & $\begin{array}{c}\text { GB } \\
(\%)\end{array}$ & $\begin{array}{c}\text { RR } \\
(\%)\end{array}$ & $\begin{array}{c}\text { MM } \\
(\%)\end{array}$ & $\begin{array}{c}\text { Other } \\
(\%)\end{array}$ \\
\hline 1997 & 2 & 43 & 45.00 & 0.00 & 0.00 & 55.00 & 0.00 & 0.00 \\
\hline 1998 & 5 & 434 & 84.71 & 10.67 & 2.72 & 1.90 & 0.00 & 0.00 \\
\hline 1999 & 8 & 796 & 17.62 & 65.17 & 4.39 & 12.81 & 0.00 & 0.00 \\
\hline 2000 & 8 & 792 & 47.16 & 43.87 & 3.62 & 4.36 & 0.99 & 0.00 \\
\hline 2001 & 8 & 621 & 72.97 & 25.36 & 1.12 & 0.36 & 0.19 & 0.00 \\
\hline 2002 & 9 & 661 & 72.80 & 23.08 & 2.37 & 0.23 & 1.53 & 0.00 \\
\hline 2003 & 9 & 845 & 72.16 & 20.09 & 5.35 & 0.01 & 2.39 & 0.00 \\
\hline 2004 & 9 & 1,030 & 90.63 & 0.00 & 0.00 & 0.00 & 9.37 & 0.00 \\
\hline 2005 & 9 & 1,645 & 84.86 & 0.00 & 0.00 & 0.00 & 14.71 & 0.43 \\
\hline 2006 & 11 & 1,756 & 93.79 & 0.21 & 6.01 & 0.00 & 0.00 & 0.00 \\
\hline 2007 & 13 & 2,471 & 82.18 & 0.14 & 17.54 & 0.00 & 0.00 & 0.00 \\
\hline 2008 & 14 & 2,652 & 86.75 & 3.43 & 4.30 & 0.01 & 5.51 & 0.00 \\
\hline 2009 & 14 & 3,172 & 69.54 & 17.44 & 4.39 & 0.00 & 0.00 & 8.63 \\
\hline 2010 & 21 & 11,189 & 58.10 & 24.30 & 1.80 & 0.03 & 0.00 & 15.77 \\
\hline $2011 /$ June & 23 & 11,808 & 61.99 & 22.29 & 4.02 & 0.91 & 0.00 & 10.79 \\
\hline
\end{tabular}

Notes: R \%: Proportion of "Real Estates" in the Portfolio; RP \%: Proportion of Real Estate "Projects" in the Portfolio; GB \%: Proportion of "Public Debt Instruments" in the Portfolio; RR \%: Proportion of "Reverse Repo" in the Portfolio; MM \%: Proportion of "Money Market Instruments" in the Portfolio.

Source: Capital Markets Board of Turkey, www.cmb.gov.tr

Table 2. Descriptive Statistics for REIT Index, from 2000 to 2010

\begin{tabular}{|l|c|c|c|c|c|c|c|c|}
\hline & \multicolumn{9}{|c|}{ REIT Index } \\
\hline Year & Mean & Median & Max. & Min. & Std. Dev. & Skewness & Kurtosis & N \\
\hline 2000 & -0.0011 & -0.0038 & 0.1974 & -0.1173 & 0.0391 & 1.0362 & 5.5514 & 245 \\
\hline 2001 & 0.0011 & -0.0025 & 0.1300 & -0.1738 & 0.0388 & -0.2064 & 2.0439 & 248 \\
\hline 2002 & -0.0012 & -0.0008 & 0.1195 & -0.1003 & 0.0294 & 0.5001 & 2.5456 & 249 \\
\hline 2003 & 0.0019 & 0.0011 & 0.1017 & -0.1195 & 0.0244 & -0.7489 & 5.6430 & 244 \\
\hline 2004 & 0.0024 & 0.0036 & 0.0734 & -0.0638 & 0.0211 & -0.0075 & 0.7650 & 248 \\
\hline 2005 & 0.0019 & 0.0027 & 0.0526 & -0.0554 & 0.0172 & -0.2127 & 0.6852 & 251 \\
\hline 2006 & -0.0005 & 0.0005 & 0.0680 & -0.1088 & 0.0200 & -0.8377 & 4.2879 & 250 \\
\hline 2007 & 0.0005 & 0.0010 & 0.0627 & -0.0836 & 0.0165 & -0.5636 & 4.4246 & 249 \\
\hline 2008 & -0.0041 & -0.0035 & 0.0882 & -0.0818 & 0.0223 & -0.1378 & 1.9746 & 249 \\
\hline 2009 & 0.0036 & 0.0043 & 0.0539 & -0.0832 & 0.0181 & -0.6625 & 2.4762 & 250 \\
\hline 2010 & 0.0011 & 0.0011 & 0.0843 & -0.0807 & 0.0171 & 0.0015 & 4.6218 & 247 \\
\hline
\end{tabular}

Source: Istanbul Stock Exchange, www.ise.org 
Table 3. The January Effect in REITs, from 2000 to 2010

\begin{tabular}{|l|c|c|c|}
\hline$R_{t}=a_{1}+a_{2} D_{2 t}+a_{3} D_{3 t}+\ldots \ldots \ldots+a_{12} D_{12 t}+e_{t}$ & Value & t-stat \\
\hline Constant & Coefficients & 0.1163 & -1.52 \\
\hline February & $\mathrm{a}_{1}$ & -0.0825 & $-2.14^{* *}$ \\
\hline March & $\mathrm{a}_{2}$ & -0.1166 & -0.92 \\
\hline April & $\mathrm{a}_{3}$ & -0.0504 & -2.48 \\
\hline May & $\mathrm{a}_{4}$ & -0.1333 & -0.81 \\
\hline June & $\mathrm{a}_{5}$ & -0.0459 & $-1.89^{* * *}$ \\
\hline July & $\mathrm{a}_{6}$ & -0.0982 & $-2.29^{* *}$ \\
\hline August & $\mathrm{a}_{7}$ & -0.1230 & -1.32 \\
\hline September & $\mathrm{a}_{8}$ & -0.0721 & -1.14 \\
\hline October & $\mathrm{a}_{9}$ & -0.0628 & -1.23 \\
\hline November & $\mathrm{a}_{10}$ & -0.0677 & -0.35 \\
\hline December & $\mathrm{a}_{11}$ & -0.0201 & \\
\hline
\end{tabular}

$*, * *$, and $* * *$ indicate statistical significance at the $1 \%, 5 \%$, and $10 \%$ levels, respectively.

Table 4. The Day of the Week Effect in REITs, from 2000 to 2010

\begin{tabular}{|l|c|c|c|}
\hline$R_{t}=a_{1}+a_{2} D_{2 t}+a_{3} D_{3 t}+a_{4} D_{4 t}+a_{5} D_{5 t}+e_{t}$ & Value & t-stat \\
\hline Constant & Coefficients & -0.1158 & $-2.92^{*}$ \\
\hline Tuesday & $\mathrm{a}_{1}$ & 0.0764 & 0.93 \\
\hline Wednesday & $\mathrm{a}_{2}$ & 0.2115 & $4.17 *$ \\
\hline Thursday & $\mathrm{a}_{3}$ & 0.2396 & $4.62 *$ \\
\hline Friday & $\mathrm{a}_{4}$ & 0.2756 & $4.98^{*}$ \\
\hline
\end{tabular}

$*, * *$, and $* * *$ indicate statistical significance at the $1 \%, 5 \%$, and $10 \%$ levels, respectively.

Table 5. The Turn of the Month Effect in REITs, from 2000 to 2010

\begin{tabular}{|l|c|c|c|}
\hline$R_{t}=a_{1}+a_{2} D_{2 t}+e_{t}$ & Value & t-stat \\
\hline Constant & Coefficients & 0.0134 & 0.76 \\
\hline Turn of the Month & $\mathrm{a}_{1}$ & 0.0351 & $1.83^{*}$ \\
\hline
\end{tabular}

$*, * *$, and $* * *$ indicate statistical significance at the $1 \%, 5 \%$, and $10 \%$ levels, respectively. 